\title{
New faunistic records of the genus Limonia MeIgen (Limoniidae, Diptera, Insecta) from the
}

\section{Balkan region}

\author{
Levente-Péter Kolcsár, Tibor OláH, Robert Veres, Edina TöröK \& Lujza KereszTeS
}

\begin{abstract}
Summary: Three species of Limonia Meigen (Diptera: Limoniidae) are recorded here for the first time from countries within the Balkan region. Here we report Limonia pannonica (KowARz, 1868) from the Republic of Macedonia, L. phragmitidis (SCHRANK, 1781) from Greece, and L. splendens (KunTZE, 1920) from Montenegro and Serbia.
\end{abstract}

Key words: Limonia splendens, Limonia pannonica, Limonia phragmitidis, distribution, genitalia, wings

\section{Introduction}

Short-palped crane flies (Limoniidae) are the largest tipuloid family, with about 10,600 recognized species (Oosterbroek 2017). Some authors suggest that the family is paraphyletic, having highly divergent tipuloid-like features in regards of their general morphology and genetic structures (PETERSEN et al. 2010, ZHANG et al. 2016). The genus Limonia is the type genus of the Limoniinae subfamily and contains 28 species in the West-Palaearctic area (Starý 2017, Oosterbroek 2017). Species of the genus are medium sized, with body length and wings both varying from $6 \mathrm{~mm}$ to $17 \mathrm{~mm}$ (StarÝ 1990, Starý and Salmela 2004, Starý 2017). Body colour across the species ranges from yellow to black. The wings are mostly transparent, but some are spotted or have dark markings, or a combination of both. Many Limonia species are widely distributed and can be common in various habitats (for example Limonia macrostigma (SCHUMMEL, 1829), and Limonia nubeculosa Meigen, 1804) (Salmela 2001, Kramer 2011, KolcSÁr et al. 2013). However some have a far more restricted distribution or are known only from specific countries such as Limonia aquilina StarÝ, 1984 (Czech Republic, Slovakia and Finland (Jukka SAlmela pers. comm. ), Limonia messaurea messaurea MENDL, 1971 (Sweden, Finland, and North Korea), Limonia nussbaumi StarÝ and FreIDBERG, 2007 (Eastern Mediterranean to the Middle East) (Starý and Barták 2005, Salmela 2012, Koç et al. 2016). Larvae are phytophagous, mycetophagous or detritivorous, living in various substrates like mud, sand, rotting wood, and wet leaf litter or are associated with the soft fruiting bodies of various fungi (Kramer 2011, KrivosheINA and KrivosheINA 2011, OOSTERBroek 2017).

Despite the fact that they are conspicuous and occur in high numbers in their habitats, Limonia appear to be insufficiently studied in the Balkans and here we report new records of three Limonia species.

\section{Material and Methods}

Specimens were collected from Macedonia, Montenegro and Greece between 2010 and 2012. Material was preserved in $70 \%$ ethanol and is stored in Diptera Collection of the Faculty of Biology and Geology, Babeş-Bolyai University, Cluj-Napoca, Romania (DCBBU). The material was identified by KolCsÁr L.-P. and KereszTes L. using an Olympus SZ61 stereomicroscope. Layer photos were taken using an Olympus SZ61 stereomicroscope (in the case of the wings) or using an Optika microscope (for genitalia) equipped with a Canon 650D camera and a LM Digital SLR Adapter. Layer photos were combined using Zerene Stacker software. All collection data are listed in Table 1 and also are available on the TransDiptera Online Database (KolCsÁR et al. 2017).

\section{Results}

During our investigation a number of 649 specimens, belonging to Limonia pannonica (Kowarz, 1868), Limonia phragmitidis (SCHRANK, 1781) and Limonia splendens KUNTZE, 1920 were identified. We list in the text only the locations which represents the first record for a species from a country. For a complete list of data see Table 1. 
New faunistic records:

Limonia pannonica (KOWARZ, 1868) (Fig. 1-3, 4A.).

Material examined: Republic of Macedonia, Vevcani, Jablanica mts., Jabalanica NP, $1407 \mathrm{~m}$, $41.2491^{\circ} \mathrm{N} 20.5623^{\circ} \mathrm{E}, 05.05 .2012,2$ males, leg. TöröK E., Kolcsár L.-P., Keresztes L.; Bratin Dol, Pelister mts., brook, $875 \mathrm{~m}, 41.0694^{\circ} \mathrm{N} 21.2344^{\circ} \mathrm{E}$, 04.05.2012, 1 male, 2 females, leg. Kolcsár L.-P.

Distribution: A West-Palaearctic species, reported from the following European countries: Austria, Czech Republic, Hungary, Italy, Moldavia, Romania, Slovakia, European and Asian parts of Turkey, and Ukraine. From the Balkans it is reported from Albania, Bulgaria, Greece and Serbia (OOSTERBRoEK 2017). Here we note it new to Macedonia (Fig. 1).

Remarks: Despite its distribution within Central Europe to Anatolia, it is a poorly known species. Specimens have been collected mostly in semi-dry to dry habitats in warm deciduous forests and foreststeppes (STARÝ 2009) or dry pine forests (STARÝ and Oosterbroek 2008, Kolcsár et al. 2013). Ujvírosi et al. (2011) reported the species (a single specimen) from wetland (along marshy springs), but most probably the fly was a stray from nearby dryer habitats. We collected the species from dry sweet chestnut (Castanea sativa) forest in Vevcani, and from pine (Pinus sp.) forest in Bratin Dol. This fly is on the Red List of threatened species in the Czech Republic (STARÝ and BARTÁK 2005). The femora, wing and male genitalia are scarcely illustrated in literature and we present here the first photos of these features. (Fig. 2, Fig. 3, Fig. 4A).

Limonia splendens (KunTZE, 1920) (Fig. 4B, 5-7.).

Material examined: Montenegro, Rasova, Tara Canyon, Đurđevića Tara Bridge, 737 m, N 43.1484 $\mathrm{N} 19.2924^{\circ} \mathrm{E}, 09.05 .2010,8$ males, 2 females, leg. Kolcsár L.-P.; Gruda, Lovcen mts., Cetinje, 680 $\mathrm{m}, 42.3873^{\circ} \mathrm{N} 18.9330^{\circ} \mathrm{E}, 12.05 .2010,3$ males and 1 female, leg. Kolcsár L.-P. Serbia, Kopaonik, Kopaonik Mts., $1600 \mathrm{~m}, 43.2981^{\circ} \mathrm{N} 20.7871^{\circ} \mathrm{E}$, 22.06.2017, 1 female, leg. KolcsÁr L.-P., TöröK E.; Kopaonik, Kopaonik Mts., 1744 m, $43.3137^{\circ} \mathrm{N}$ $20.8373^{\circ}$ E, 22.06.2017, 13 males, 1 females, leg. KOLCSÁR L.-P., TÖRÖK E.

Distribution: This is a West-Palaearctic species, previously reported from the following countries: Austria, Bulgaria, Greece, Hungary, Italy, Macedonia, Slovakia, Georgia, Asiatic part of Turkey (Van province) (OOSTERbroek 2017). Here we report the fly for the first time from Montenegro and Serbia (Fig. $5)$.

Remarks: Originally the fly was described as a species in its own right (KUNTZE 1920), but later was synonymised as just a colour variation of Limonia pannonica (LACKSCHEWITZ 1928, LACKSCHEWITZ and Pagast 1940). Starý (1990) demonstrated that L. pannonica and $L$. splendens were in fact different from each other and from the similar L. maculipennis (MeIGEN, 1818) in the colouration of the abdomen, the structure of the hypopygium (Fig. 2,6) and wing features (Fig. 4). The femora, wing and the male genitalia are rarely illustrated and here we present the first photos of them (Fig. 6-7, Fig. 4B). Little is known about the biology of the species and specimens noted here were collected from dry Pinus sp. and Quercus sp. forests, during early May in Montenegro, and in an alpine pasture with some small Picea sp. trees in Serbia.

Limonia phragmitidis (SCHRANK, 1781) (Fig. 8-9.).

Material examined: Greece, Galani, Nestos River, $48 \mathrm{~m}, 41.0919^{\circ} \mathrm{N} 24.7595^{\circ} \mathrm{E}, 06.05 .2011,1$ male, leg. Kolcsár L.-P.

Distribution: This is a widely distributed species in the Palaearctic area, and is present in most European countries. In the Balkan region it is known from Albania, Bosnia-Herzegovina, Bulgaria, Croatia, Serbia and Turkey (European part: Edirne, Kirklareli). Here we report it for the first time from Greece (Fig. 8).

Remarks: The species is one of the most abundant and most frequently collected Limonia species in Europe (Fig. 9), commonly found in wet wooded, and humid ecosystems, having semi-aquatic larvae (Drake 2011, Kolcsár et al. 2013). We collected the species in willow (Salix sp.) forest along the Nestos River.

\section{Aknowledgements}

The authors thank Bea Lózer, István Funkenhauzer, Cintia Horváth, Réka Kiss, András Varró and Wolfram Graf for collecting specimens. We thank Pete Boardman for his comments on the text. This study was financially supported partly by a grant of the Romanian Ministry of National Education, CNCS-UEFISCDI-nr. PN-II-ID-PCE-20124-0595 and by scholarships from the Collegium Talentum, Hungary.

\section{References}

Drake C.M. (2011) The Diptera of a wet woodland in Devon. Dipterists Digest 18: 9-26.

Koç H., Özgül O. and Hasbenli A. (2016). Limoniidae (Diptera) fauna of the Marmara region with 23 new records for Turkey. Turkish Journal of Zoology 40(2): $1-13$.

KolcsÁr L.-P., TöröK E. and Keresztes L. (2013) Craneflies (Diptera: Tipuloidea) and phantom craneflies (Diptera: Ptychopteridae) fauna around a metropolis (Cluj-Napoca, Romania). Acta Scientiarum Transylvanica 21: 66-78.

Kolcsár L.-P., Veres R. and Keresztes L. (2017) TransDiptera Online Database. http://transdiptera.ro. 


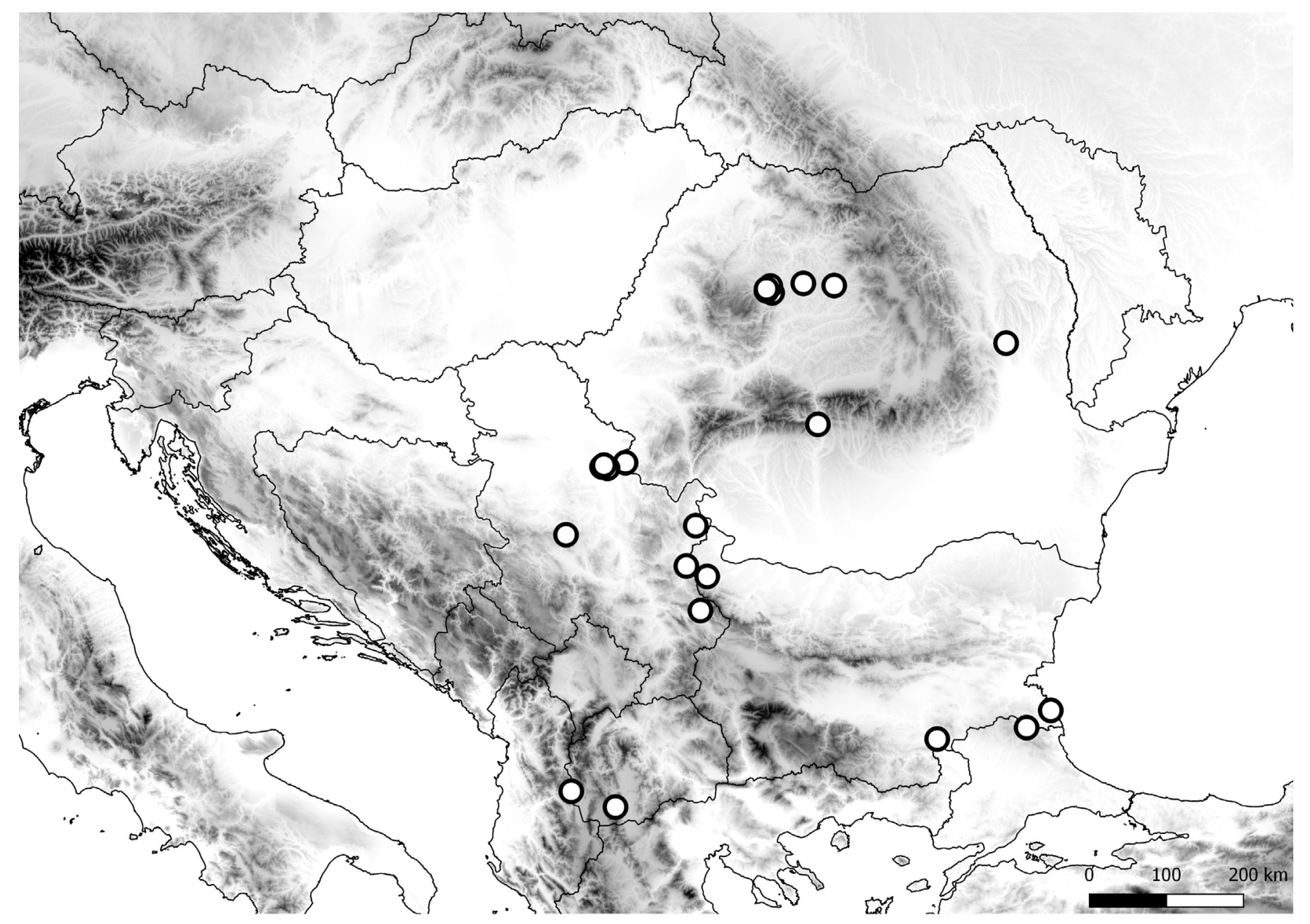

Fig. 1. Location of collection sites of Limonia pannonica (KowARZ, 1868).
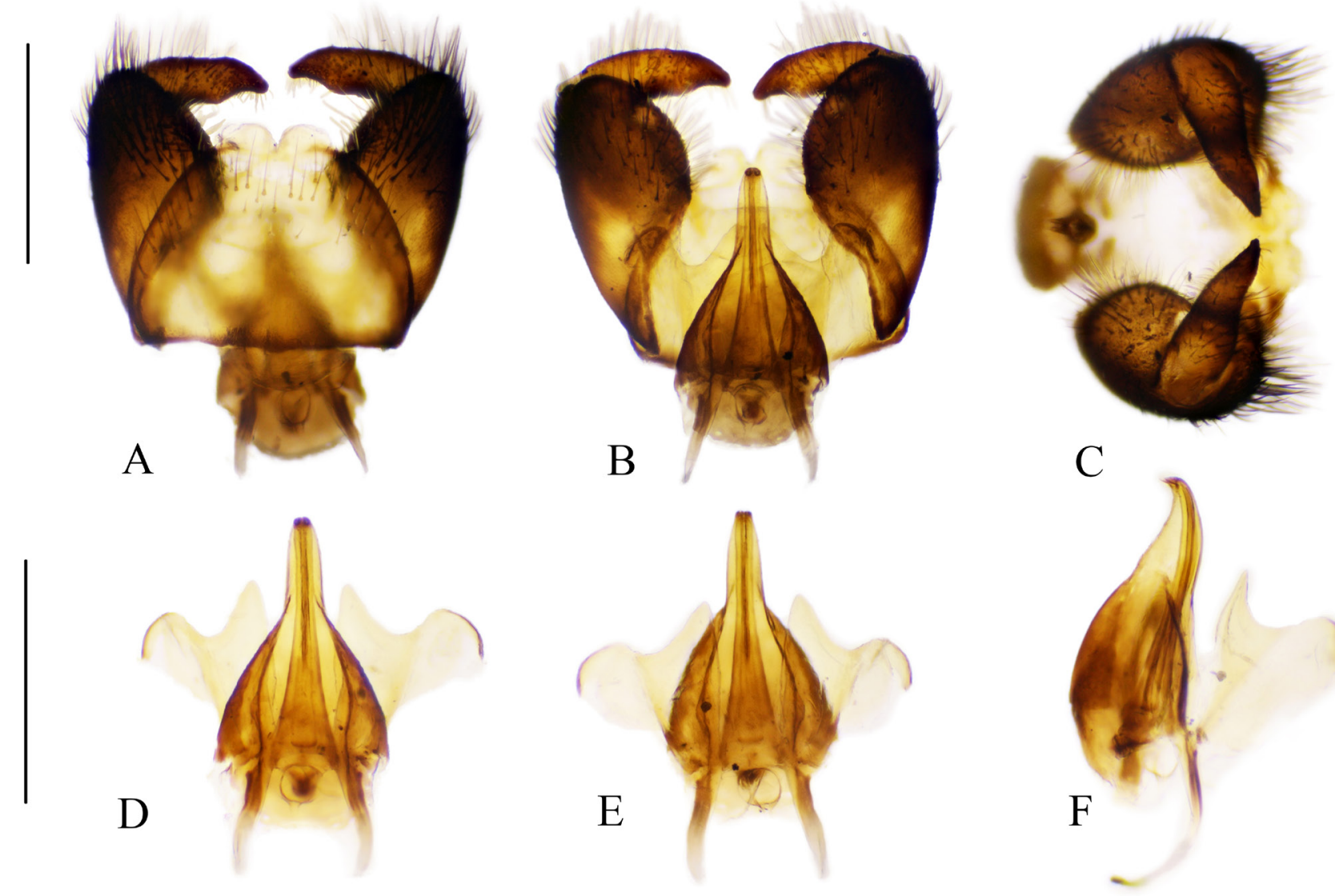

Fig. 2. Limonia pannonica (KowArz, 1868): A-C male hypopygium, A - dorsal view, B - ventral view, C - caudal view; D-F aedeagal complex, D - dorsal view, E - ventral view, F - lateral view. Scale bars: $0.5 \mathrm{~mm}$ 
A

$\mathrm{B}$

$\mathrm{C}$

Fig. 3. Femora of Limonia pannonica (Kowarz, 1868): A - fore, B - mid, C - hind. Scale bar: $0.5 \mathrm{~mm}$.
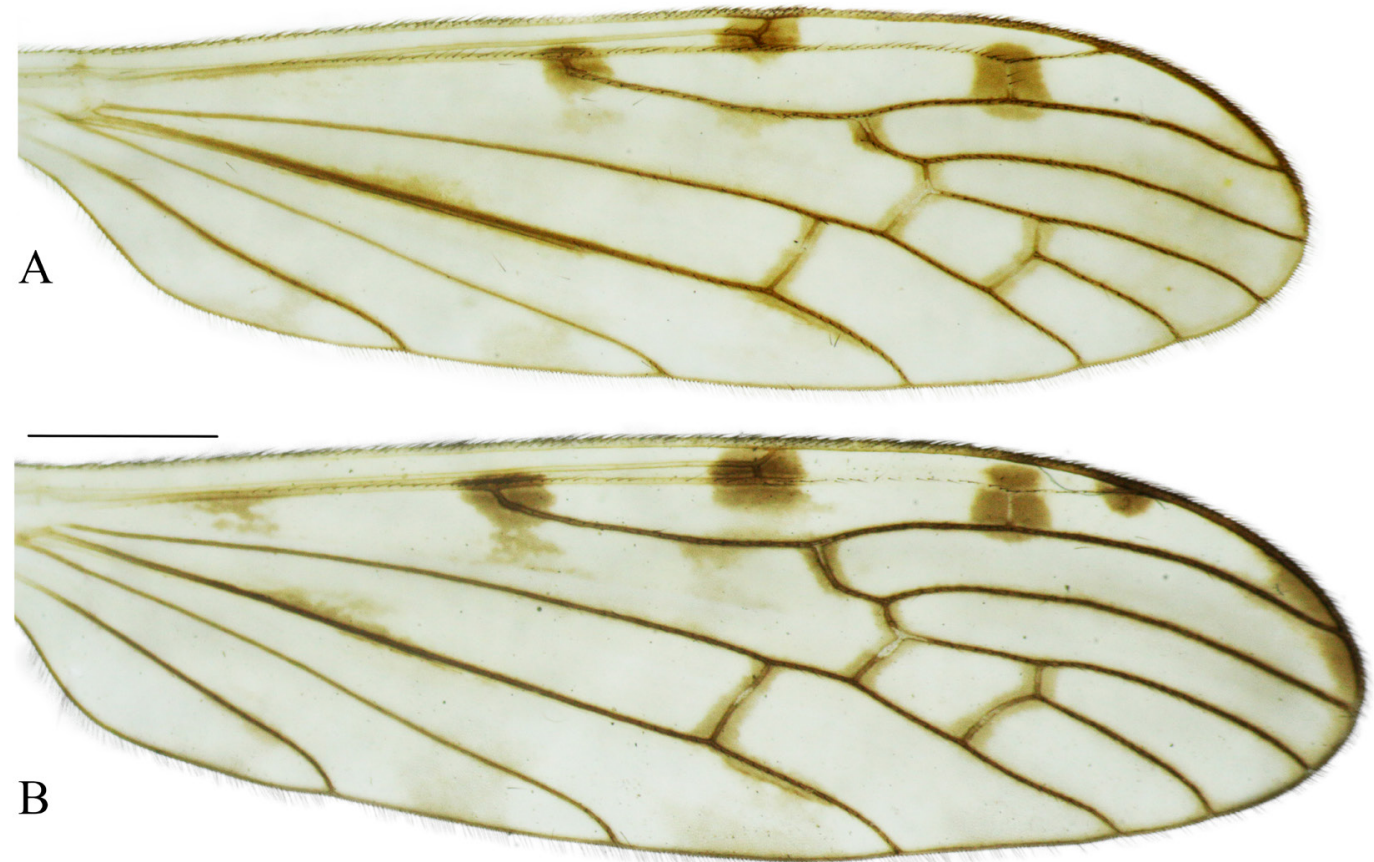

Fig. 4. Wings: A - Limonia pannonica (KowARZ, 1868), B - Limonia splendens (KunTZE, 1920). Scale bar: 1 mm.

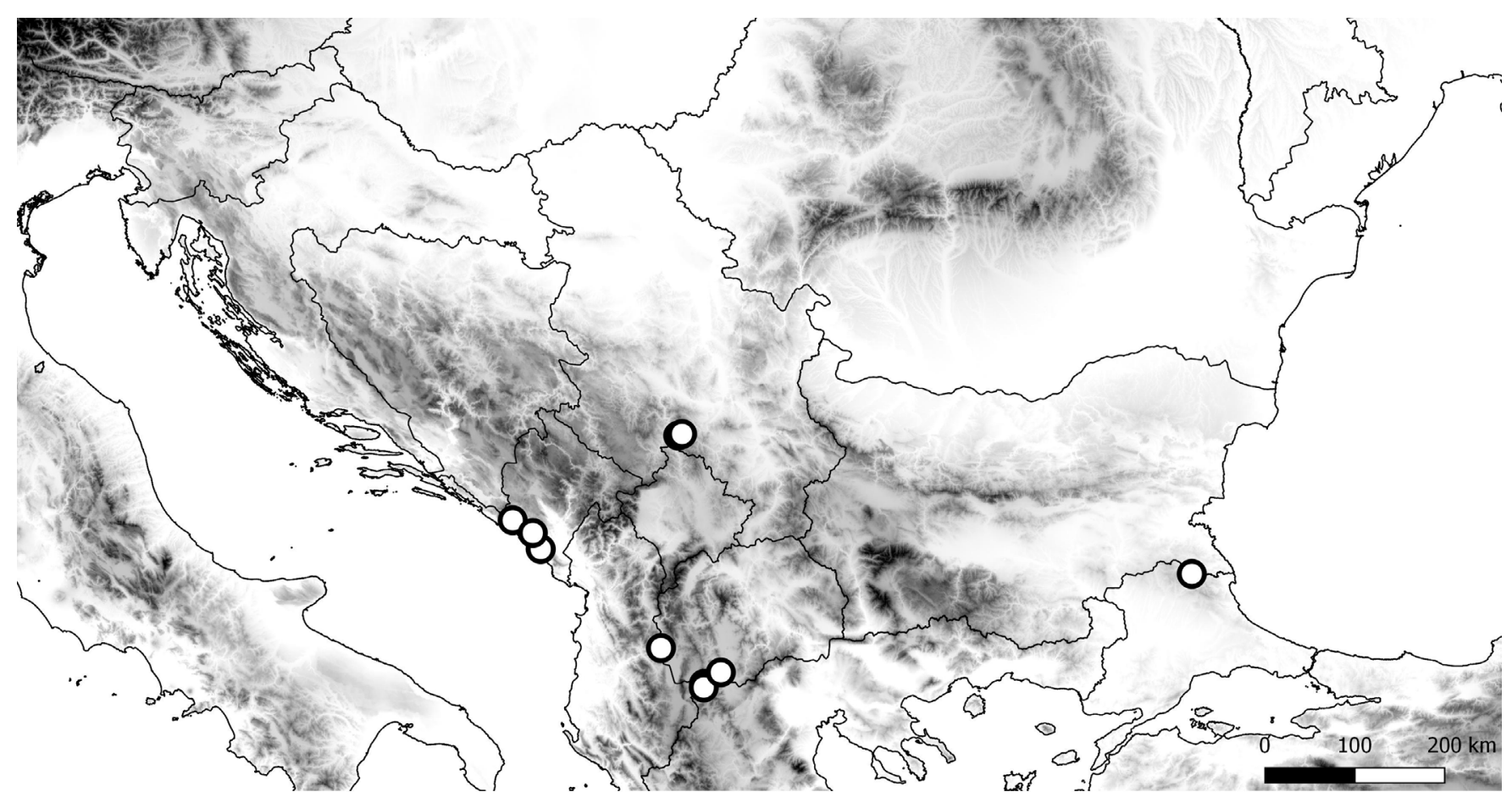

Fig. 5. Location of collection sites of Limonia splendens (KunTZE, 1920). 

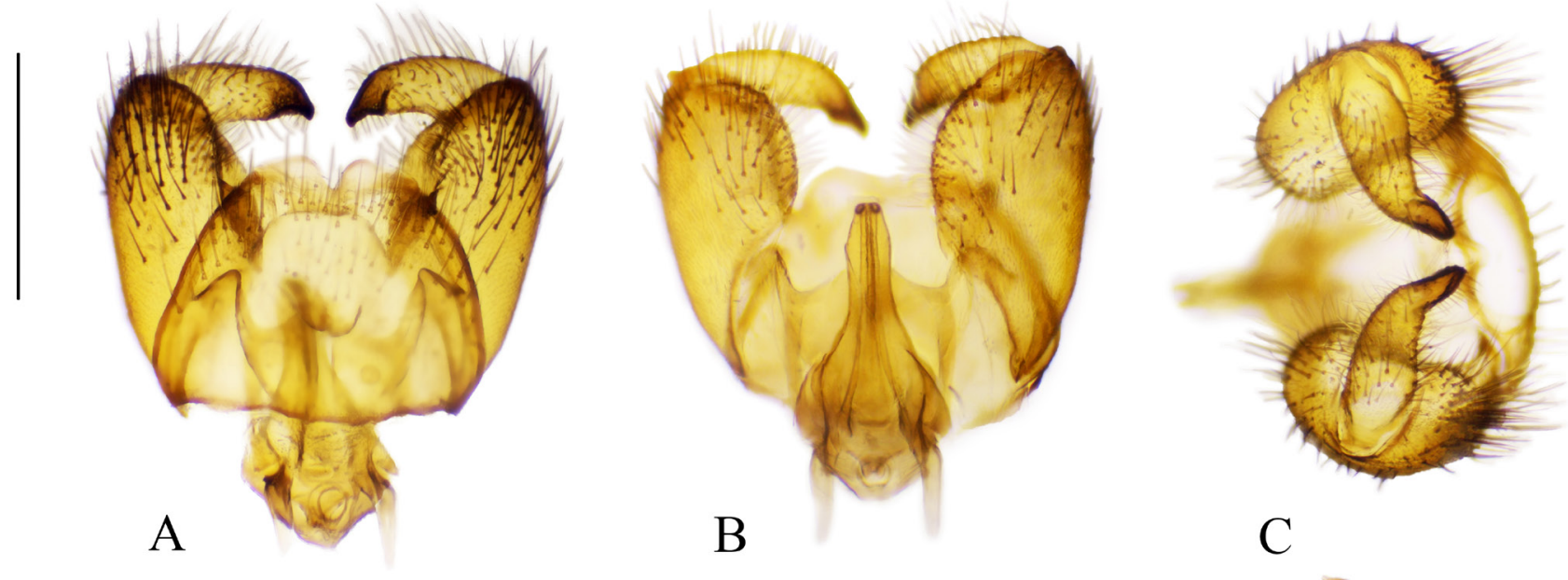

$\mid$
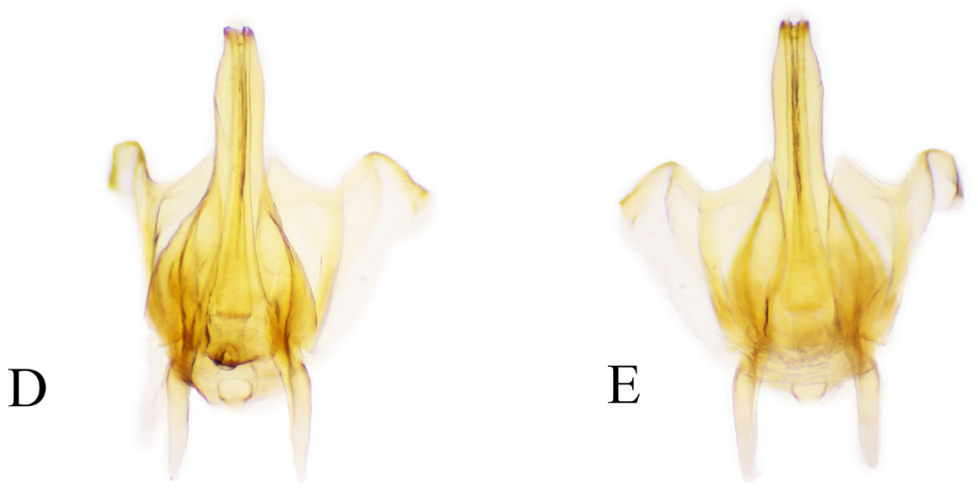

$\mathrm{C}$

$\mathrm{F}$

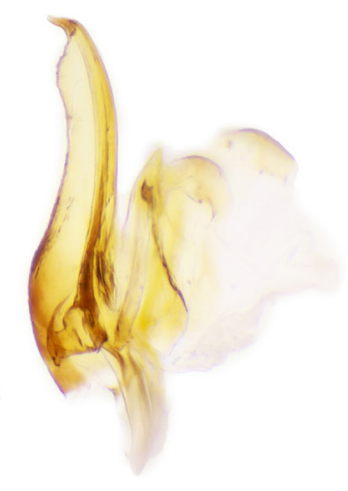

Fig. 6. Limonia splendens (Kuntze, 1920): A-C male hypopygium, A - dorsal view, B - ventral view, C - caudal view; D-F aedeagal complex, D - dorsal view, E - ventral view, F - lateral view. Scale bars: $0.5 \mathrm{~mm}$.

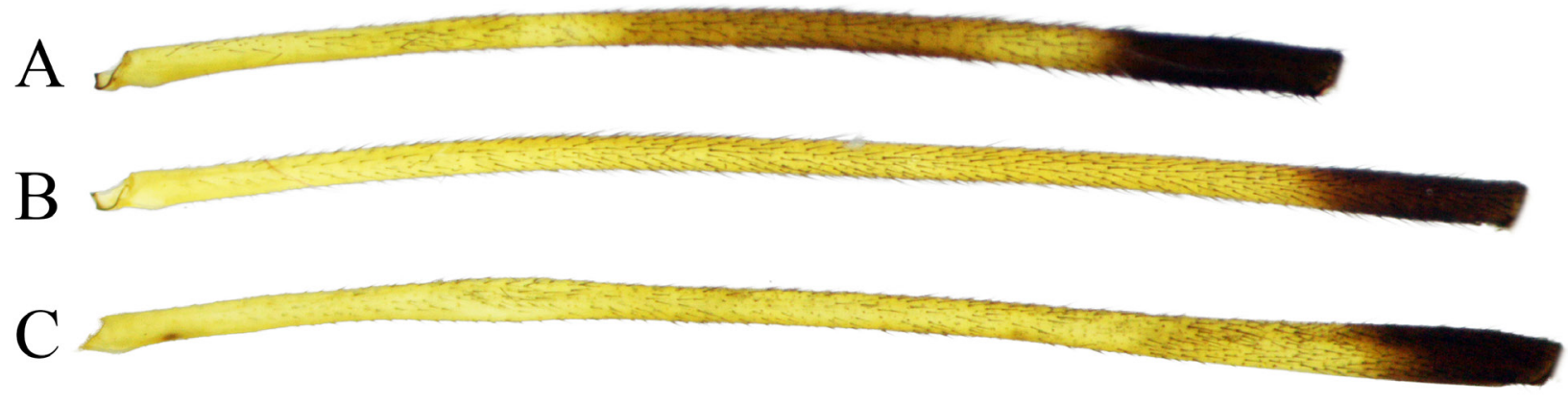

Fig. 7. Femora of Limonia splendens (Kuntze, 1920): A - fore, B - mid, C - hind. Scale bar: $0.5 \mathrm{~mm}$.

accessed on: 20.11.2017. https://doi. org/10.18426/ OBM.5sskmllli3ip0

Kramer J. (2011) The Craneflies of Leicestershire and Rutland (VC55). Lesops 26: 1-30.

Krivosheina N. P. and Krivosheina M. G. (2011) Key to terrestrial crane-fly larvae (Diptera, Limoniidae, Pediciidae) of Russia. KMK Scientific Press, Moscow, Russia, 294 pp.

Kuntze A. (1920) Limoniidae MeIg. Tabellen zum Bestimmen der palaarctischen Limoniinae. Zoologische Jahrbucher. Abteilung fur Systematik, Geographie und Biologie der Tiere 43: 371-432.

LACKSCHEWITZ P. (1928) Die palaearktischen Limnobiinen (Diptera) des Wiener Naturhistorischen Museums. Annalen des Naturhistorischen Museums Wien 42: 195-244.
LACKSChewitz P. and PAgast F. (1940) Limoniidae. In: LiNDNER E. (ed.), Die Fliegen der palaearktischen Region 3(5), Lief, 135, 1-16.

Oosterbroek P. (2017) Catalogue of the Craneflies of the World (Diptera, Tipuloidea: Pediciidae, Limoniidae, Cylindrotomidae, Tipulidae), http://ccw.naturalis.nl/, accessed on 20.11.2017.

Petersen M. J., Bertone M.A., Wiegmann B.M. and Courtney G.W. (2010) Phylogenetic synthesis of morphological and molecular data reveals new insights into the higher-level classification of Tipuloidea (Diptera). Systematic Entomology 35: 526-545.

SAlmela J. (2001) Adult craneflies (Diptera: Nematocera) around springs in southern Finland. Entomologica Fennica 12(3): 139-152.

SALmela J. (2012) Biogeographic patterns of Finnish 


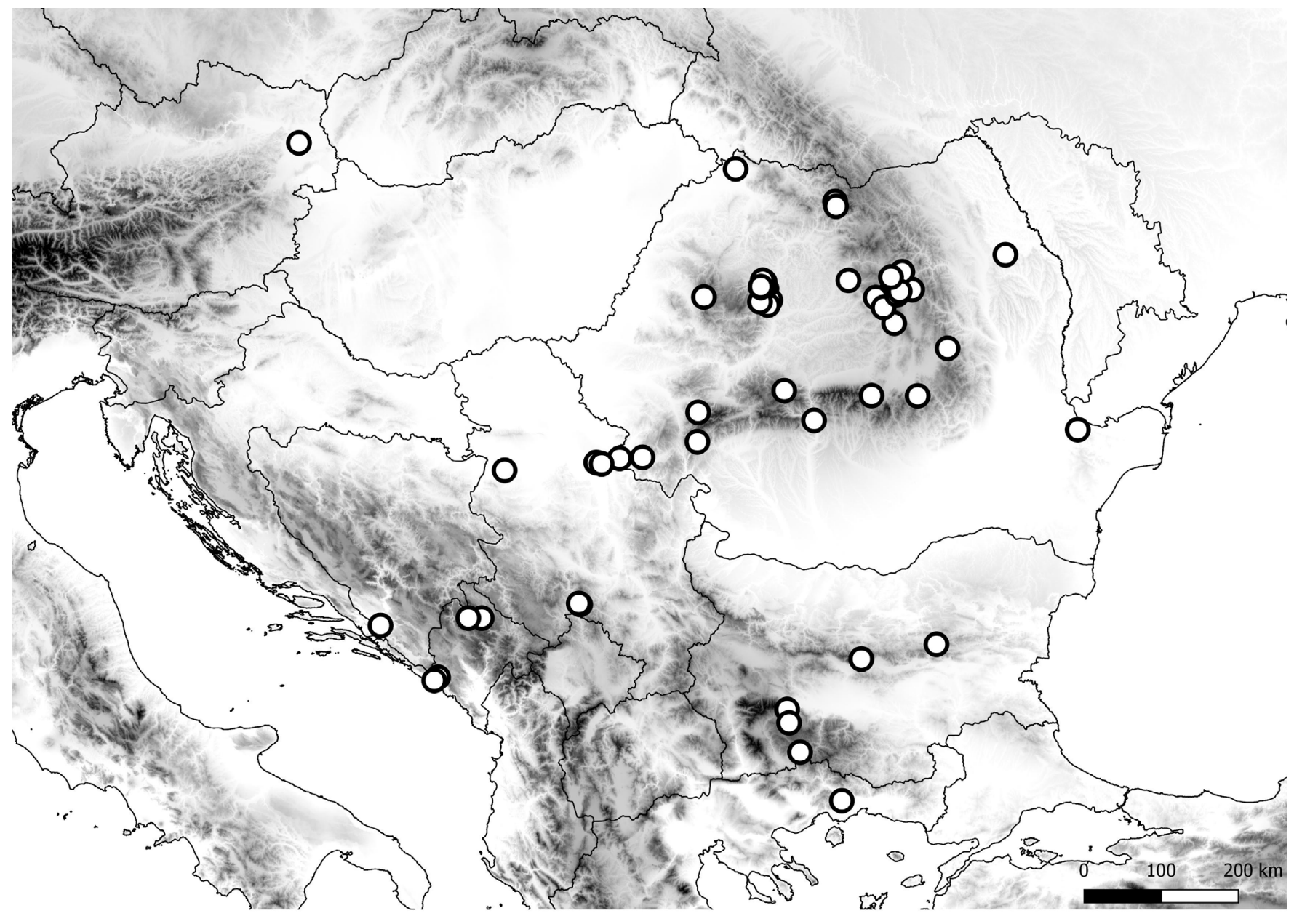

Fig. 8. Location of collection sites of Limonia phragmitidis (SCHRANK, 1781).

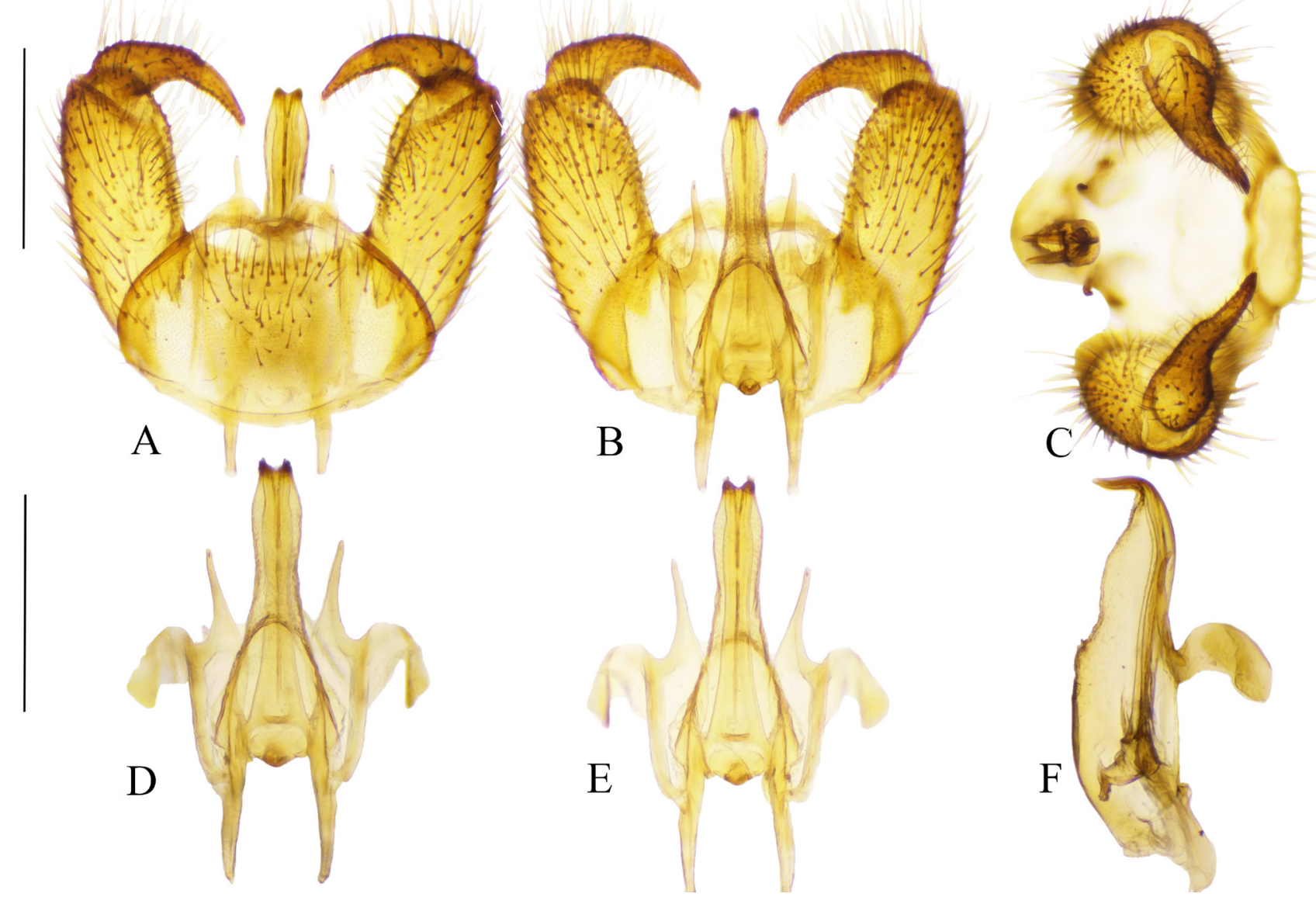

Fig. 9. Limonia phragmitidis (SCHRANK, 1781): A-C male hypopygium, A - dorsal view, B - ventral view, C - caudal view; D-F aedeagal complex, D - dorsal view, E - ventral view, F - lateral view. scale bars: $0.5 \mathrm{~mm}$ 
crane flies (Diptera, Tipuloidea). Psyche: A Journal of Entomology doi:10.1155/2012/913710: 1-20.

Salmela J. (2012) Biogeographic patterns of Finnish crane flies (Diptera, Tipuloidea). Psyche: A Journal of Entomology 2012: 1-20 doi: http://dx.doi. org/10.1155/2012/913710

StARÝ J. (1990) Limonia splendens KunTZE, 1920 reinstated as a valid species (Diptera, Limoniidae). Casopis Slezskeho Musea v Opava 39: 39-51.

STARÝ J. and BARTÁK M. (2005) Limoniidae (bahnomilkoviti). In: FARKAC J., KRÁL D. and ŠKKORPÍK (eds.): Red list of threatened species in the Czech Republic. Invertebrates. Agentura ochrany prirody a krajiny.

Starý J. (2009) Limoniidae In: RoHaceK J. and Sevcik J. (eds.): Diptera of Polana Protected Landscape Area / Biosphere Reserve (Central Slovakia). SNC SR, Administration of the PLA/BR Polana, Zvolen. StarÝ J. and SAlmela J. (2004) Redescription and biology of Limonia badia (WALKER) (Diptera: Limoniidae).

Entomologica Fennica 15(1): 41-47.

Starý J. and Oosterbroek P. (2008) New records of West Palaearctic Limoniidae, Pediciidae and Cylindrotomidae (Diptera) from the collections of the Zoological Museum, Amsterdam. Zootaxa 1922: 1-20.

Ujvárosi L., Póti T. and Kolcsár L.-P. (2011) Lószúnyogszerü diptérák (Diptera, Tipuloidea) élőhelypreferenciája és szezonális diverzitása a Vaslábi rétlápban és annak környékén (Keleti Kárpátok). In: MARKó B. and SÁrkáNY-KIss E. (eds.): A Gyergyóimedence: egy mozaikos táj természeti értékei. Presa Universitara Clujeana/ Cluj University Press: 101-118.

Zhang X., Kang Z., Mao M., Li X., Cameron S.L., DE Jong H., WANG M. and YANG D. (2016) Comparative Mt genomics of the Tipuloidea (Diptera: Nematocera: Tipulomorpha) and its implications for the phylogeny of the Tipulomorpha. PloS ONE 11(6): e0158167.
Levente-Péter KoLCSÁR

Hungarian Department of Biology and

Ecology, Centre of Systems Biology,

Biodiversity and Bioresources,

Babeș-Bolyai University, Clinicilor 5-7,

Cluj-Napoca, Romania

E-mail: kolcsar.peter@gmail.com

\section{Edina TöRÖK}

Hungarian Department of Biology and

Ecology, Centre of Systems Biology,

Biodiversity and Bioresources,

Babeș-Bolyai University, Clinicilor 5-7,

Cluj-Napoca, Romania

Romanian Academy Institute of Biology,

Splaiul Independenţei 296, 060031

București, Romania

E-mail: edinatorok7@gmail.com
Tibor OLÁH

Hungarian Department of Biology and Ecology,

Babeș-Bolyai University, Clinicilor 5-7, Cluj-Napoca, Romania

E-mail: olahtibor95@gmail.com

\section{Lujza Keresztes}

Hungarian Department of Biology and

Ecology, Centre of Systems Biology,

Biodiversity and Bioresources,

Babeş-Bolyai University, Clinicilor 5-7,

Cluj-Napoca, Romania

E-mail: keresztes2012@gmail.com
Robert Veres

Hungarian Department of Biology and Ecology,

Babeș-Bolyai University, Clinicilor 5-7, Cluj-Napoca, Romania

E-mail: veresrobi18@gmail.com

Received: 30.11.2017

Accepted: 15.12.2017

Published online: 28.12.2017

Published: 28.12.2017

Online article number: ER21201705

doi: 10.24193/entomolrom.21.5 


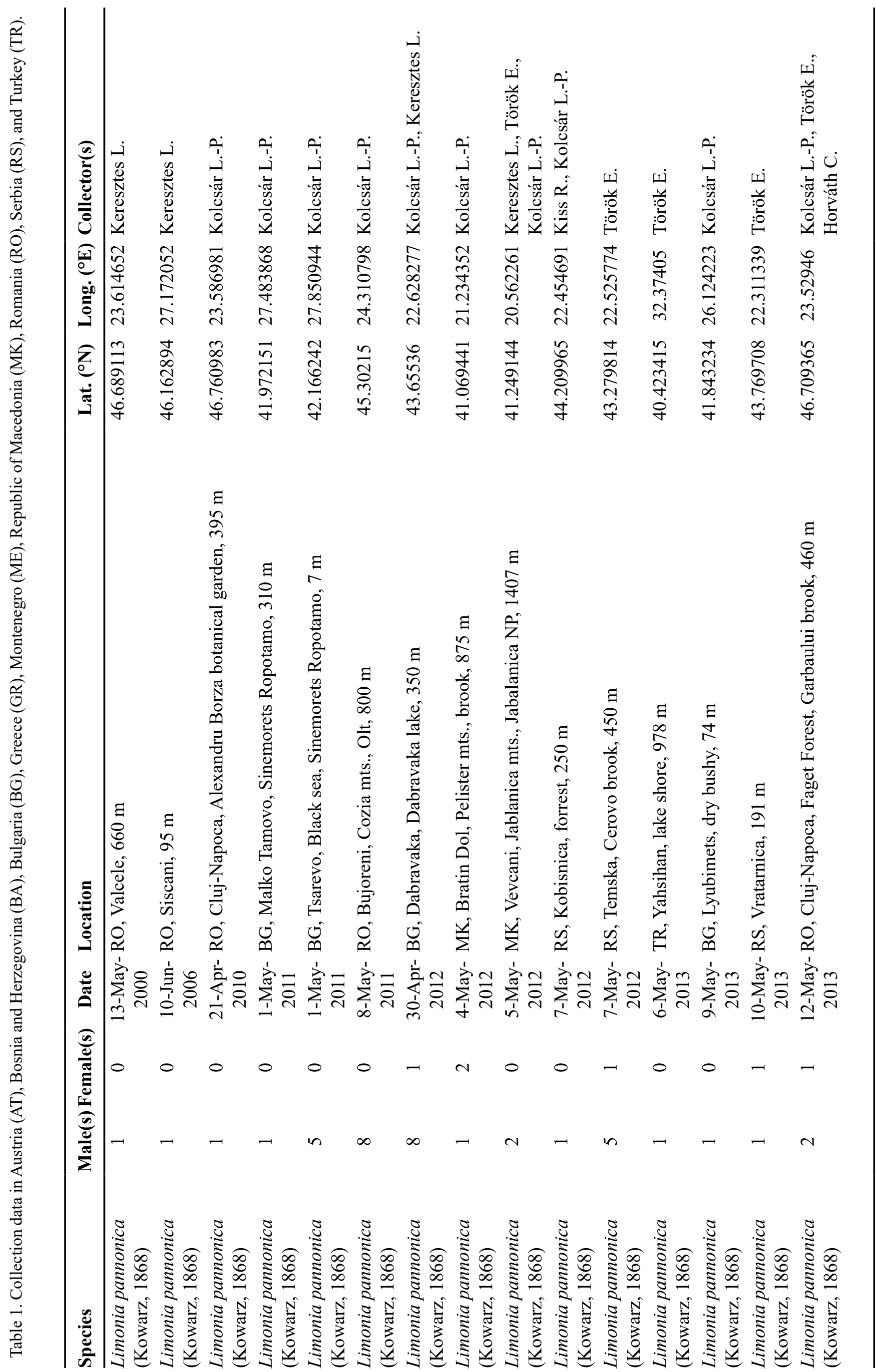




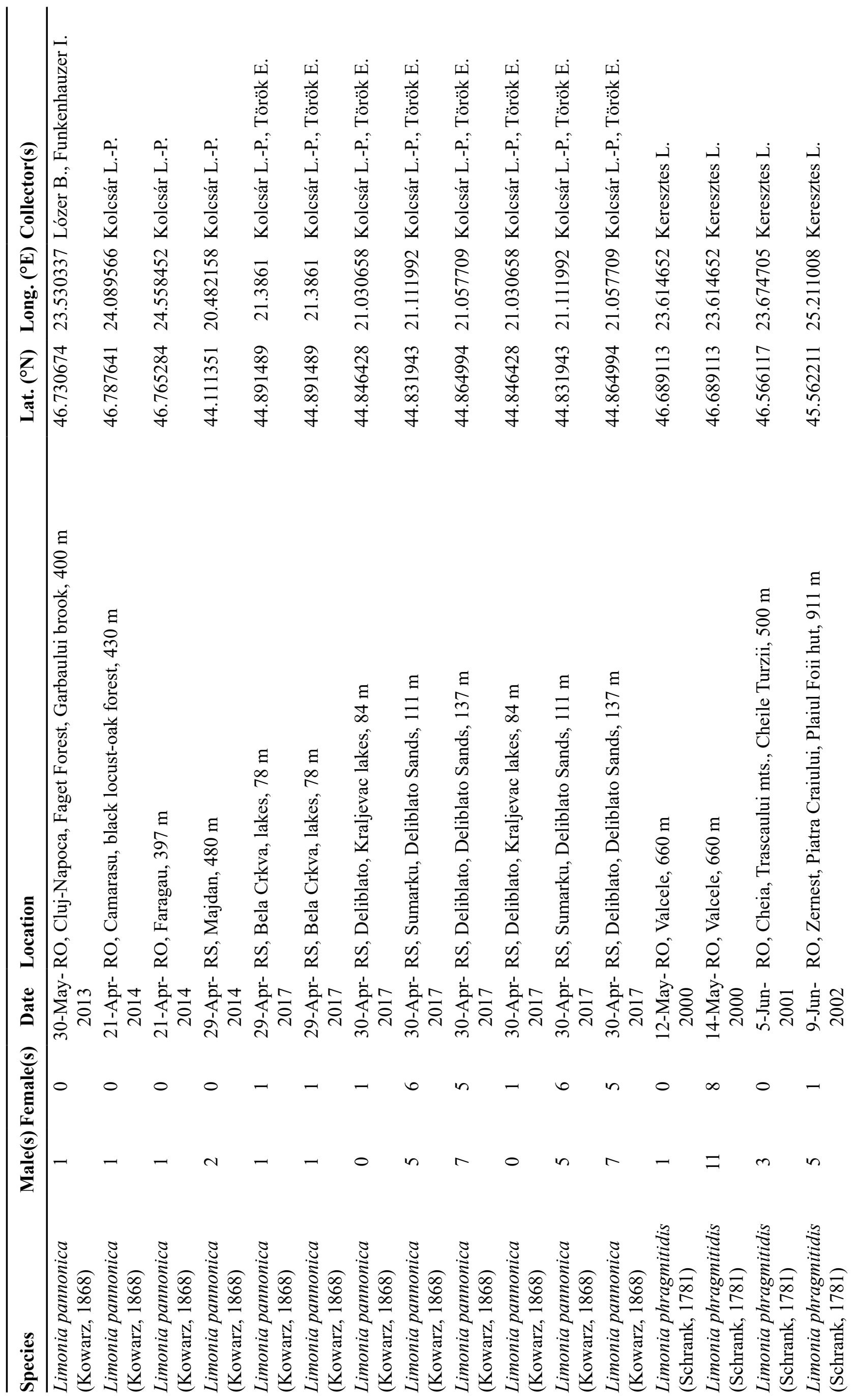




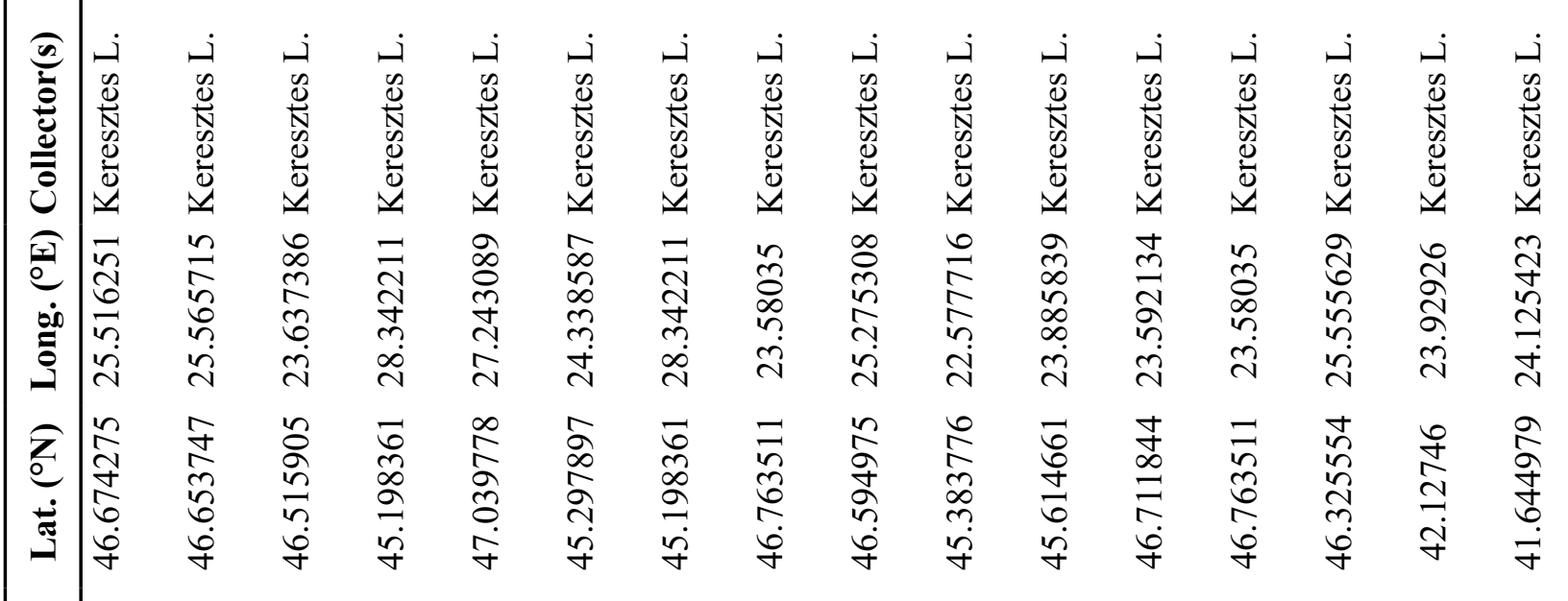

-

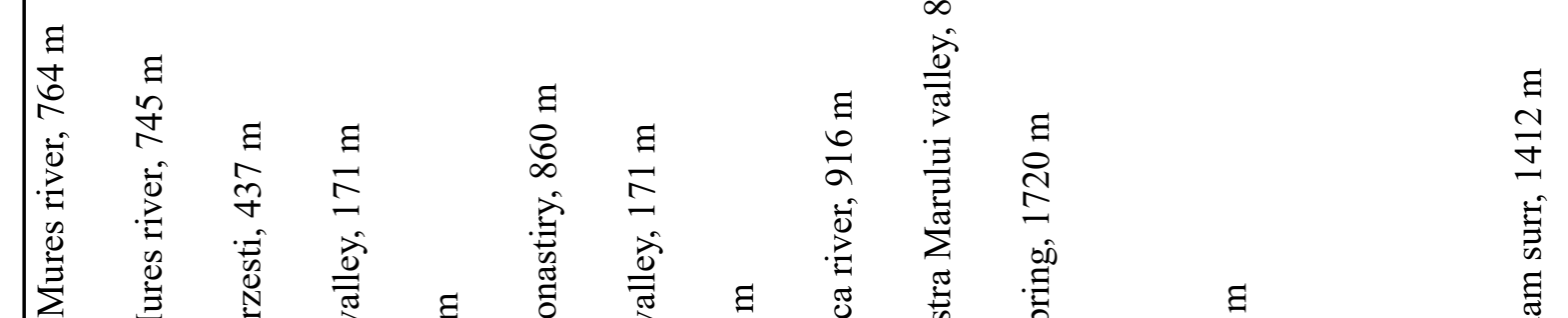

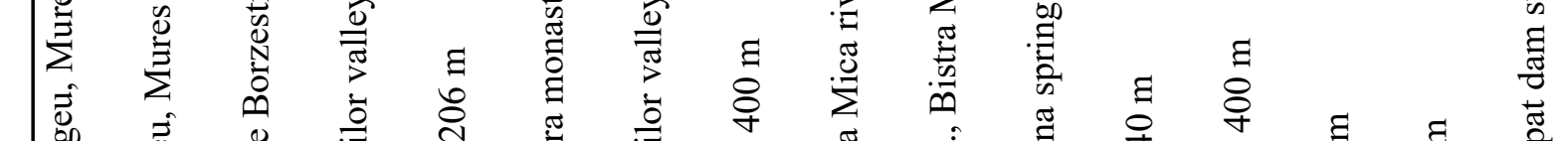

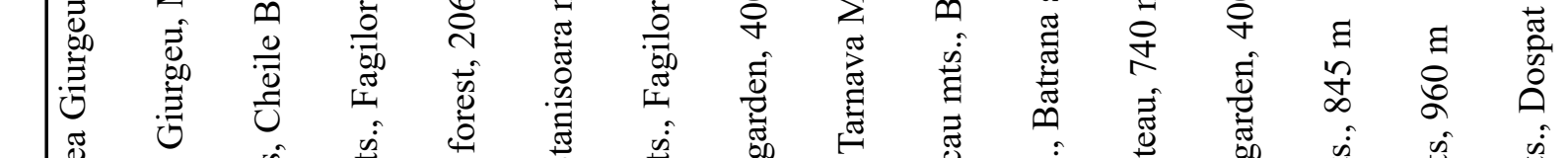

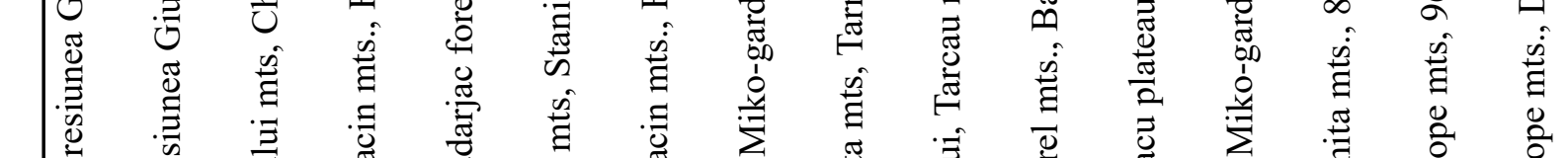

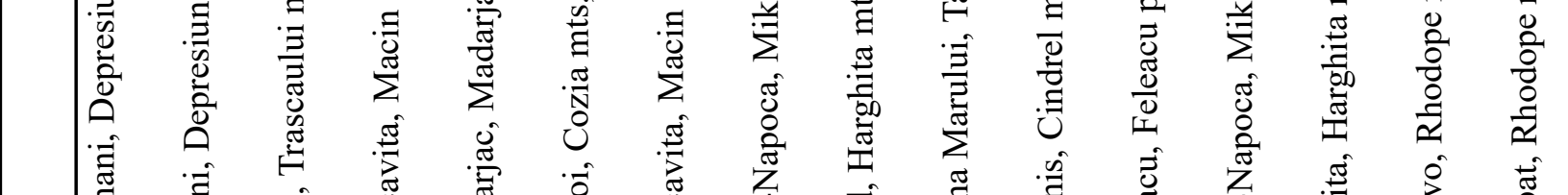

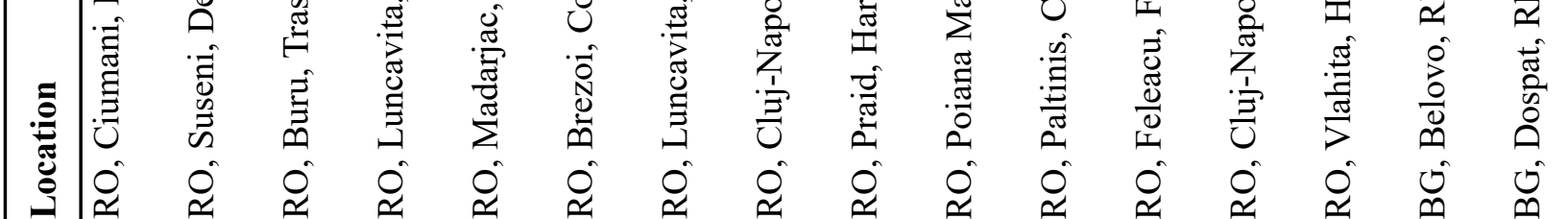

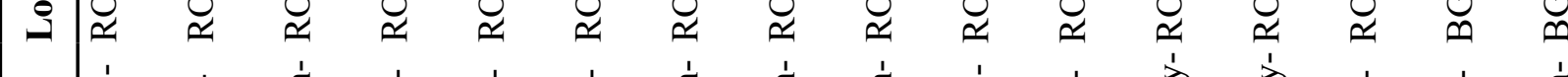

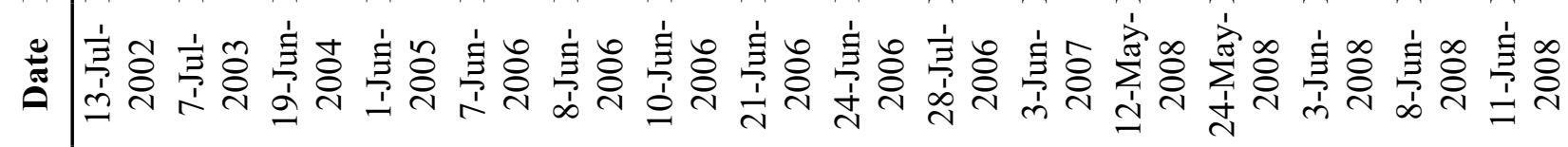

产

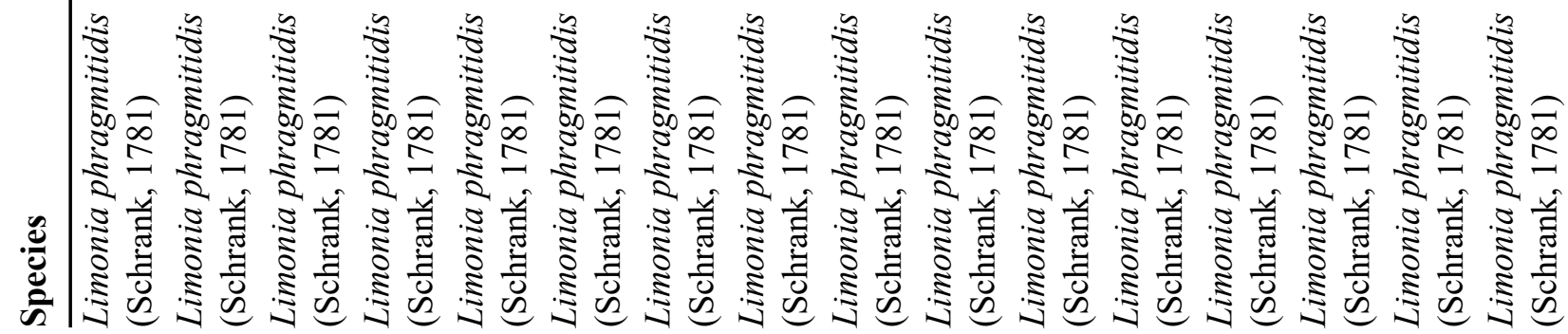




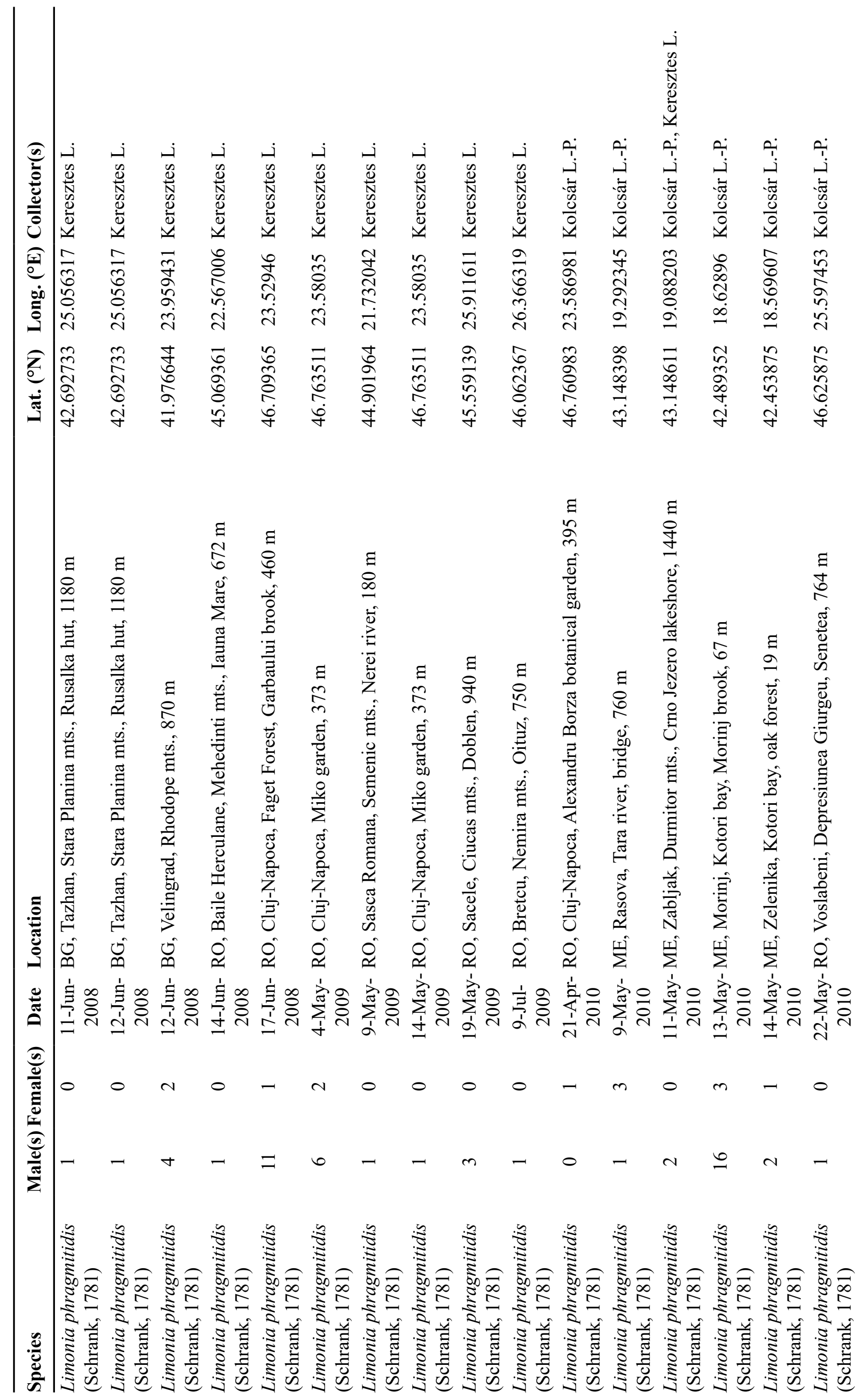




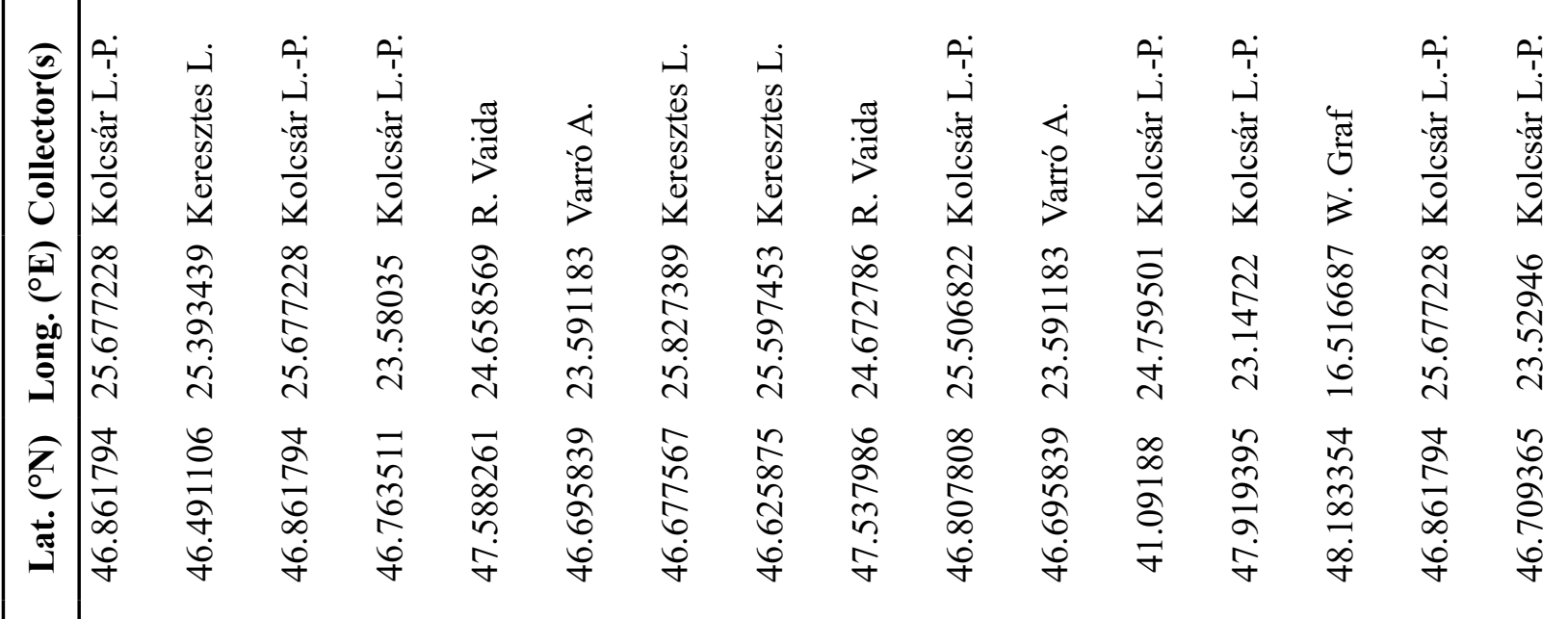

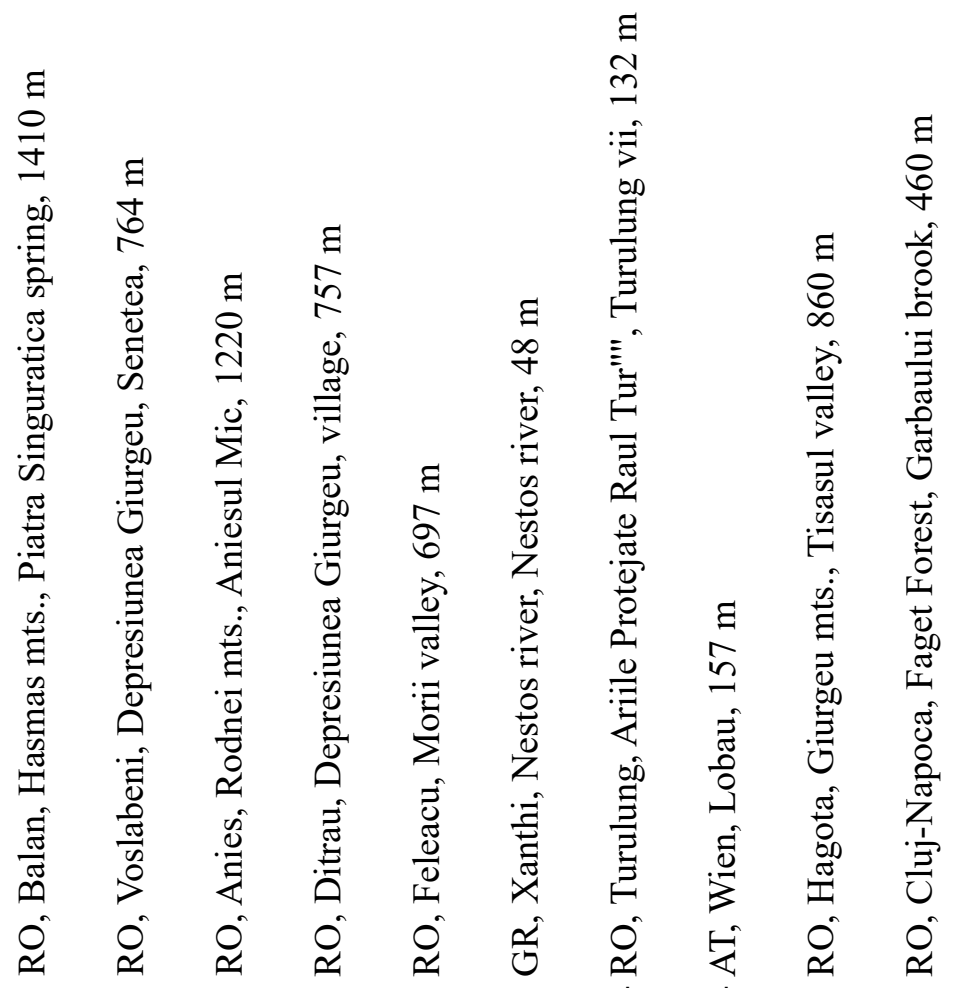

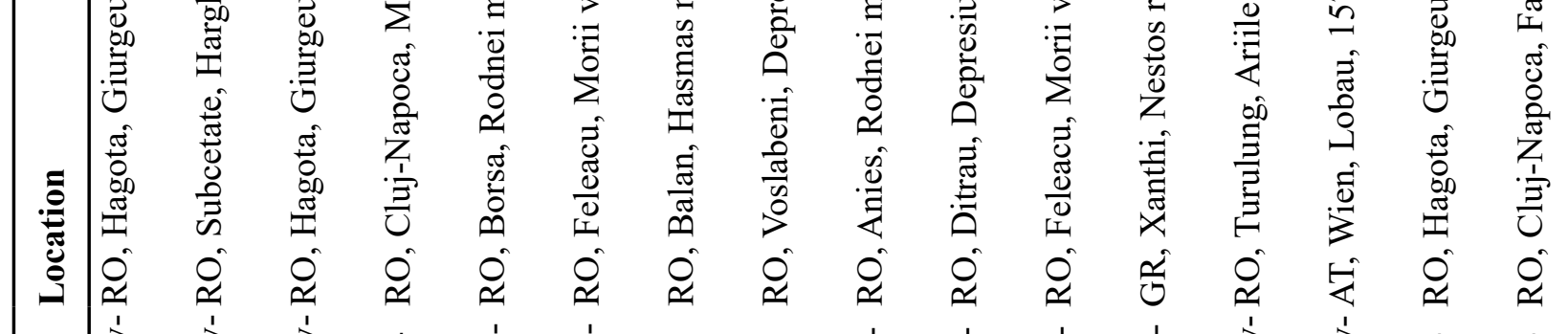

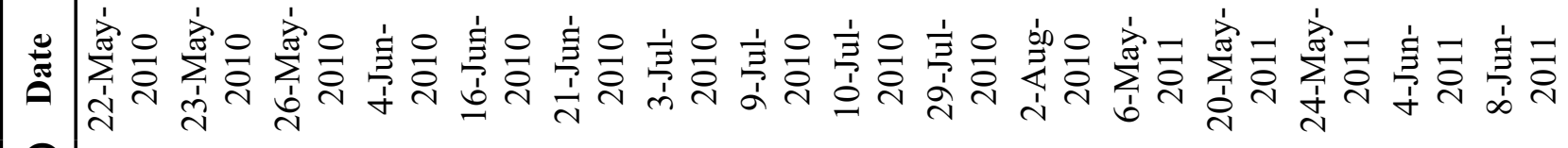

-

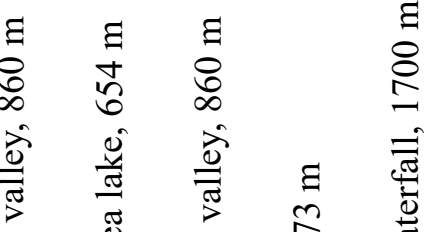

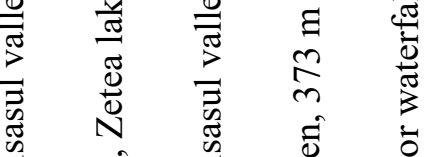

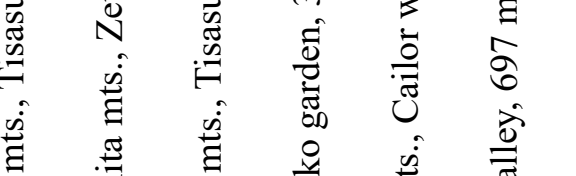

๘

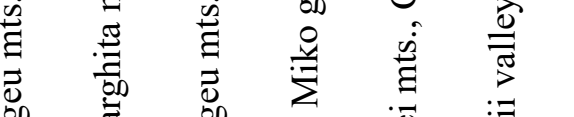

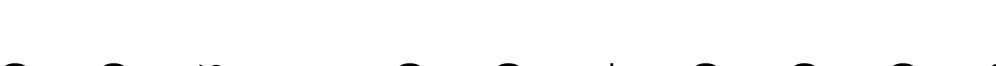




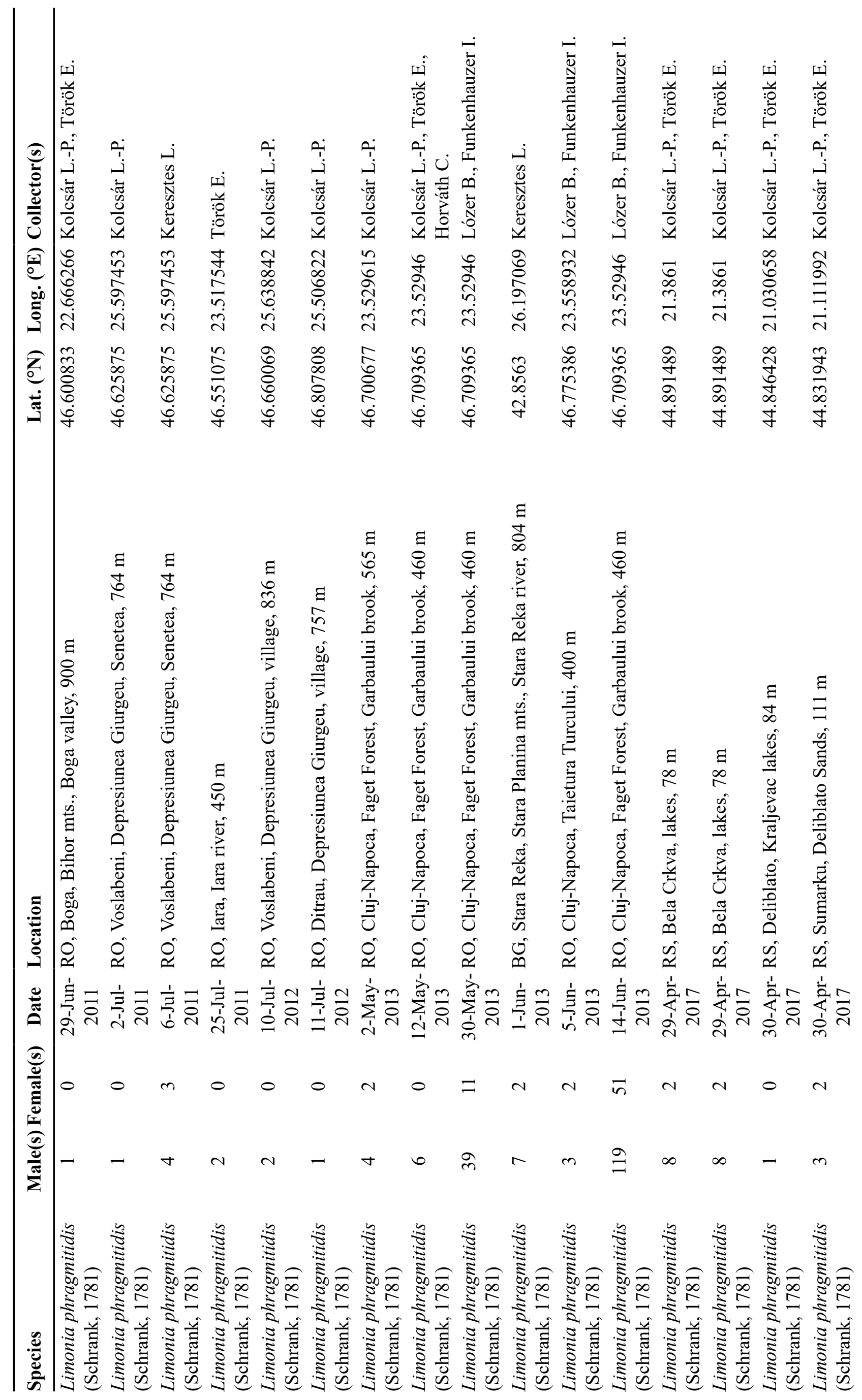




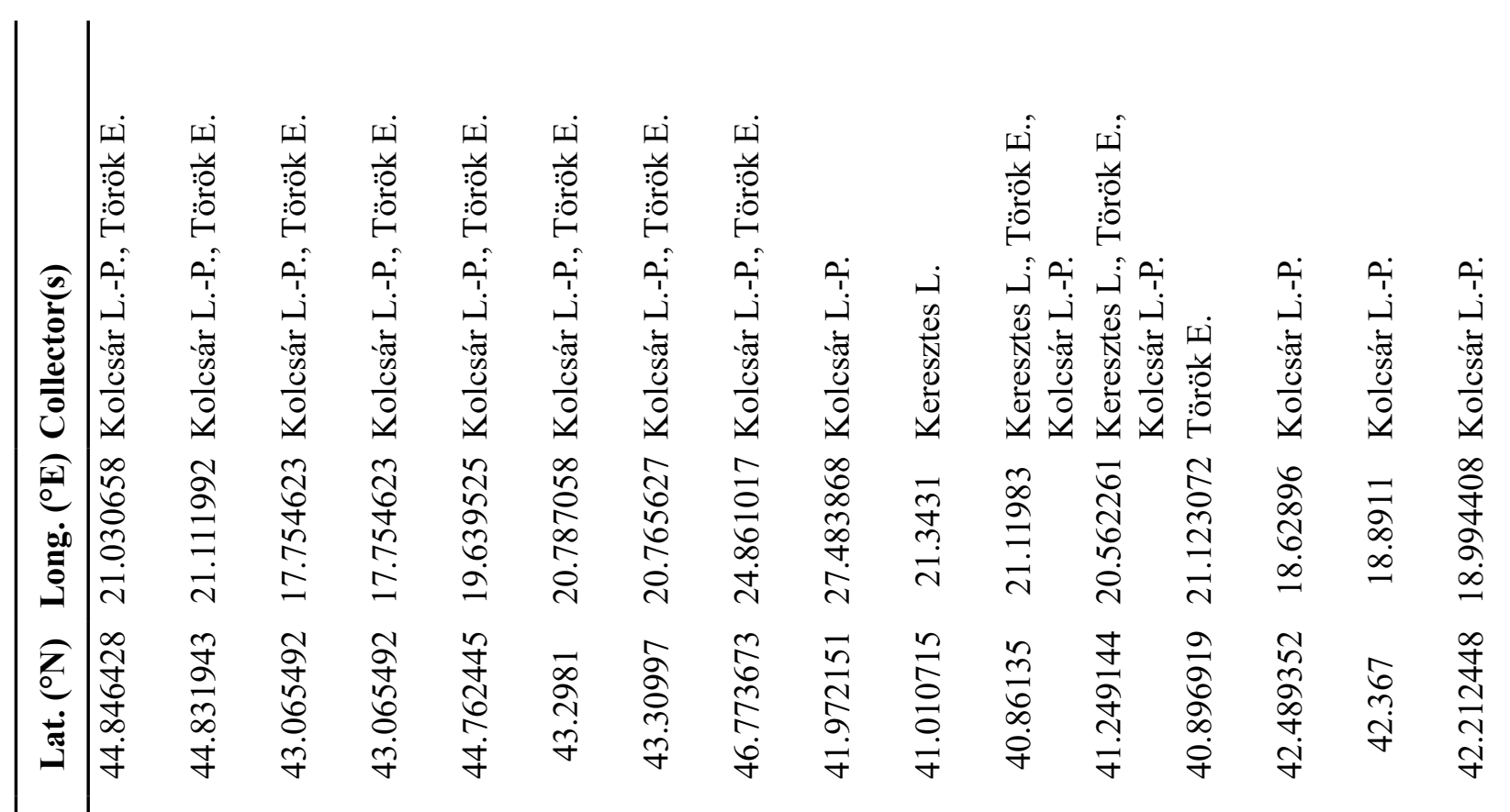

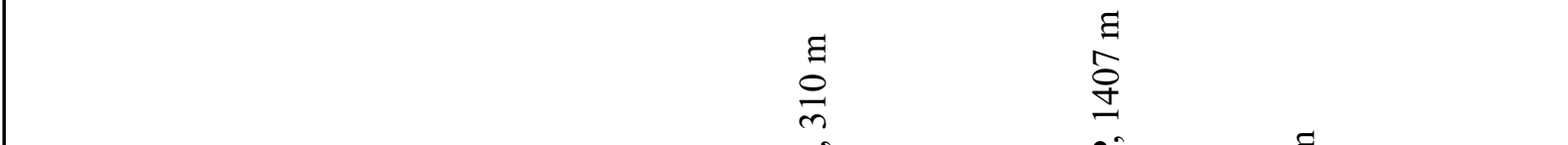

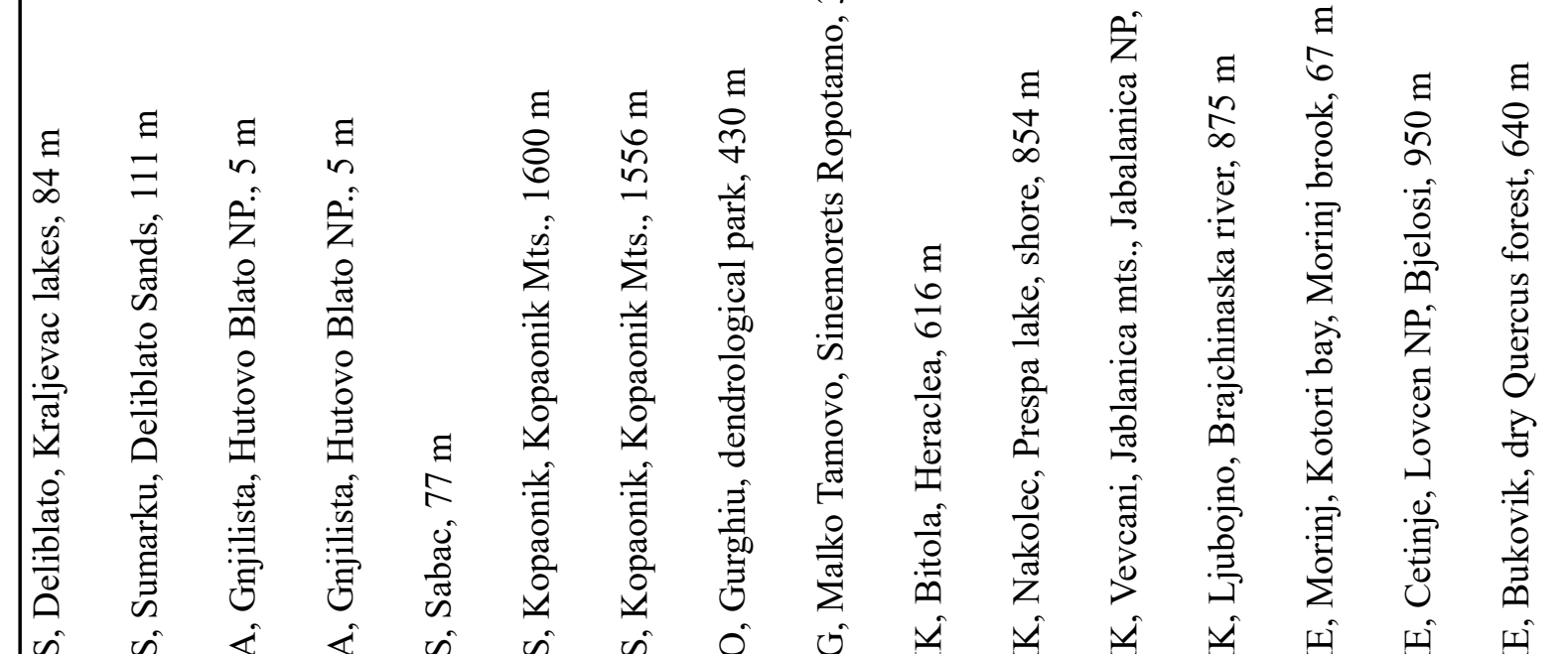

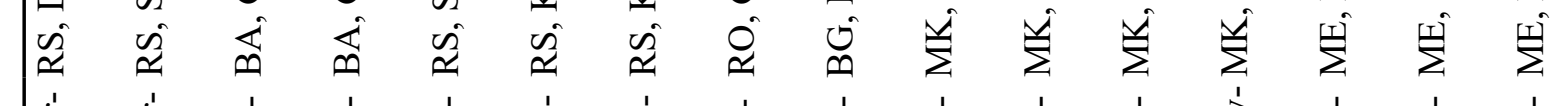

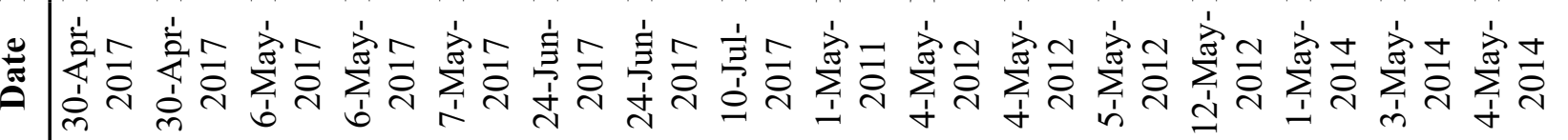

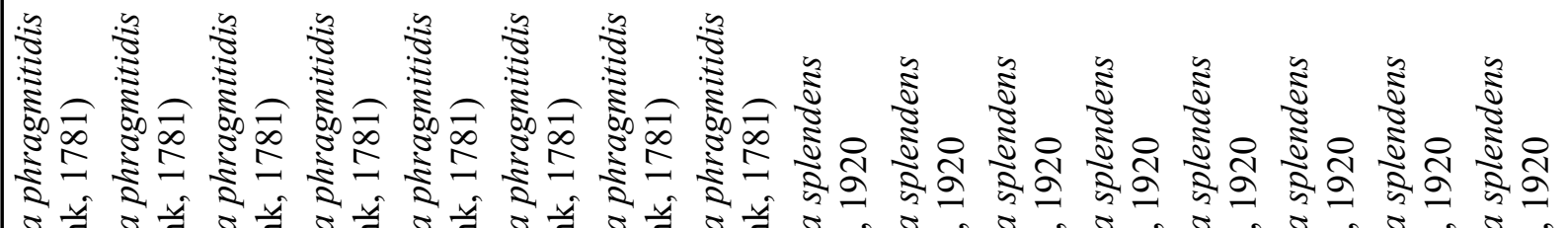

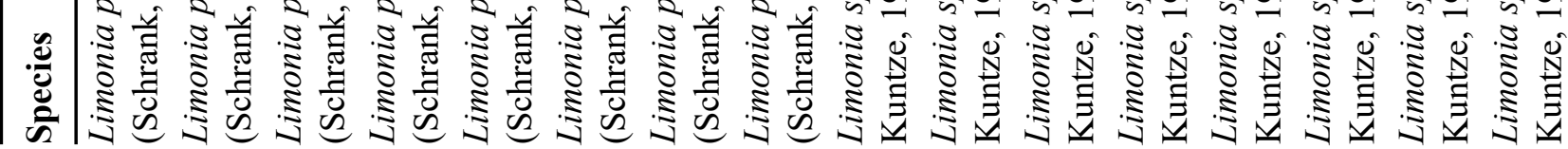




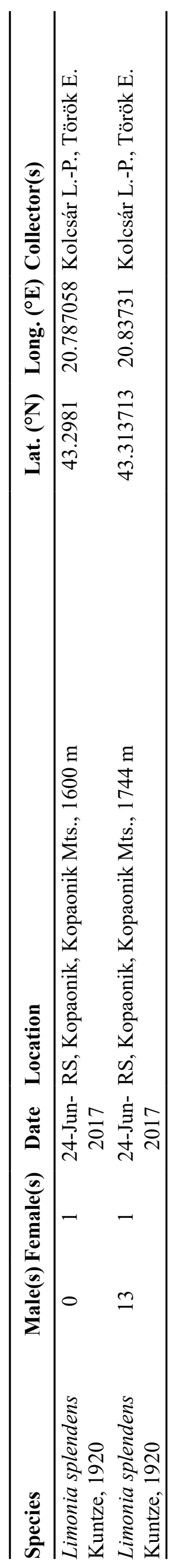

